\title{
Microstructures and Oxidation Behavior According to Nb:Mo Ratio in a Nb-Mo-Si System with Si Pack Cementation Coatings
}

\author{
Wonchul Yang ${ }^{\circledR}$, Choong-Heui Chung ${ }^{\circledR}$, Sangyeob Lee, Jong Won Lee and Joon Sik Park *® \\ Department of Materials Science and Engineering, Hanbat National University, Daejeon 34158, Korea; \\ wonchul188@gmail.com (W.Y.); choong@hanbat.ac.kr (C.-H.C.); sangyeob@hanbat.ac.kr (S.L.); \\ jwlee@hanbat.ac.kr (J.W.L.) \\ * Correspondence: jsphb@hanbat.ac.kr
}

Received: 28 October 2019; Accepted: 19 November 2019; Published: 20 November 2019

\begin{abstract}
Research is being conducted on Mo- and $\mathrm{Nb}$-based alloys that are used in the aerospace sector, including those used for advanced gas turbines and aircraft engines. There is a limit to using Mo, which has a high density among refractory metals, and a few studies exist describing the addition of $\mathrm{Nb}$ to Mo-silicide alloys. There is a lack of guidance research on the basic Nb:Mo ratio of alloys, and it is necessary to study how to improve oxidation resistance. Therefore, this study aims to improve oxidation resistance by controlling the ratio of $\mathrm{Nb}$ and $\mathrm{Mo}$ in $\left(\mathrm{Nb}_{\mathrm{x}}, \mathrm{Mo}_{\mathrm{y}}\right) \mathrm{Si}_{2}$ coating layers with $\mathrm{Si}$ pack cementation coatings on $\mathrm{Nb}-\mathrm{Mo}$ alloys. Static oxidation tests were carried out at $1200^{\circ} \mathrm{C}$ for $6 \mathrm{~h}$ to confirm the oxidation characteristics. As a result, a $\mathrm{SiO}_{2}$ or $\mathrm{SiO}_{2}+\mathrm{Nb}_{2} \mathrm{O}_{5}$ ceramic protective layer was formed on the surface. After the oxidation tests, alloys with a $\mathrm{Nb}$ content of less than 35 at.\% were found to protect the surface. The ratios of $\mathrm{Nb}$ and $\mathrm{Mo}$ in the $\mathrm{Nb}-\mathrm{Mo}$ alloy and silicide coating layer were compared, and the improvement of oxidation resistance is discussed in terms of microstructural evolution.
\end{abstract}

Keywords: coatings; oxidation; SEM

\section{Introduction}

In recent years, next-generation technology has become preoccupied with eco-friendly and economic factors, and many studies in various fields have focused on improving efficiency. Typically, the aerospace industry focuses on engine efficiency, including advanced gas turbines and aircraft engines $[1,2]$. Among the methods of improving the efficiency of an engine, much research has been conducted on increasing the operating temperatures of materials [1,2]. When selecting a new high temperature material, various factors such as melting point, density and oxidation resistance should be considered. For example, Ni-based Haynes 230 and/or Inconel 718 alloys, which have been used as turbine engine materials for decades, have an operating temperature below $\sim 1100{ }^{\circ} \mathrm{C}$ [3]. However, by reaching a service temperature of $\sim 1300{ }^{\circ} \mathrm{C}$ without a cooling system, the output power of an engine can be improved by about $50 \%$. In this regard, Mo-based alloys have been considered as alternatives [2]. Many studies have been conducted on high-temperature alloys with designs that can enhance the material properties [4-8]. For example, it has been documented that Mo-Si-B alloys showed excellent high temperature strength. Much research has been carried out on Mo-Si-B alloys of $\mathrm{Mo}_{3} \mathrm{Si}$ (A15) $+\mathrm{Mo}$ (ss) $+\mathrm{Mo}_{5} \mathrm{SiB}_{2}$ (T2) phases by adding Si and B to the ductile Mo component to increase strength at high temperatures [2,9-11]. While Mo-based alloys showed excellent mechanical properties, attempts were made to lower their densities. One route for adjusting density was to design $\mathrm{Mo}-\mathrm{Nb}$-based alloys, since the density of $\mathrm{Nb}$ is lower than that of Mo. Research has been 
conducted on $\mathrm{Nb}$-Mo-based alloys with lowered densities and improved mechanical properties at room temperature $[12,13]$. K. Chattopadhyay et al. investigated the microstructure and mechanical properties of $\mathrm{Nb}-\mathrm{Si}-\mathrm{B}$ alloys [14]. $\mathrm{N}$. Takata et al. investigated the microstructures of $\mathrm{Nb}-\mathrm{Mo}-\mathrm{Si}-\mathrm{B}$ alloys in Bcc/T1/T2 three phases by fixing the $\mathrm{Nb}$ content at 32.6 at.\% and then adjusting the $\mathrm{Si}$ and $\mathrm{B}$ contents [15]. J.M. Byun et al. tried to improve the mechanical properties by adding $\mathrm{Nb}$ to a Mo-Si-B alloy with powder metallurgy, and compared the manufactured $\mathrm{Nb}-\mathrm{Mo}-\mathrm{Si}-\mathrm{B}$ alloy with a Mo-Si-B counterpart [13].

While they have high melting points and excellent strength at high temperatures $[2,12,13,16]$, the alloys are known to show serious defects upon exposure to high temperatures under ambient atmosphere $[4,16,17]$. For Mo-based alloys, the Mo component is known to have poor oxidation resistance as a result of the formation of volatile oxides $\mathrm{MoO}_{3}(\mathrm{~g})$ at temperatures above about $500{ }^{\circ} \mathrm{C}$ [16-19]. When Mo-based alloys were exposed to high temperatures in air, they usually disintegrated. For Mo-Si-B alloys, while the oxidation behavior is enhanced due to the formation of borosilicate, the surface still needs protection. In addition, $\mathrm{Nb}$-based alloys also have been reported to have poor oxidation behavior due to $\mathrm{Nb}_{2} \mathrm{O}_{5}$ (s) oxides having non-protective properties at high temperatures, and because oxidation rapidly forms porous layers instead of continuous oxide layers [20-22]. In order to enhance the oxidation behavior, many studies have been reported, such as pack cementation, spray coatings, plasma coatings, etc. [16,23,24]. Among the examined coating routes, pack cementation processing appears to be an effective manner to produce oxidation resistant coatings. The pack cementation process can provide mass production and ensure high bond strength between the coating materials and substrates. Further, complex-shaped component parts can be uniformly coated, since the coating method adopts gas diffusion to substrates [16].

A number of studies have been conducted to improve oxidation resistance by forming $\mathrm{SiO}_{2}$ or $\mathrm{Al}_{2} \mathrm{O}_{3}$ oxide on the surface in a high temperature oxidation environment with pack cementation coatings $[16,17,20,21,25]$. K. Choi et al. discussed the growth and oxidation behavior of coating layers after Si pack cementation coatings on Mo-3Si-1B (wt.\%) alloys [16]. K. Choi et al. also investigated the oxidation behavior under the condition of $1350{ }^{\circ} \mathrm{C}$ after forming a $\mathrm{MoSi}_{2}$-silicide layer on the surface of TZM alloys. In addition, the oxidation behavior was discussed in terms of the diffusion pathway and microstructure changes in the Mo-Si-O system [17]. J. Cheng et al. investigated the microstructures and oxidation behavior of the coating layers at $1100{ }^{\circ} \mathrm{C}$ after forming silicide layers in $\mathrm{Nb}-\mathrm{Si}-\mathrm{B}$ alloys $[20,21]$. Y. Liu et al. investigated the oxidation behavior in terms of microstructures by controlling the $\mathrm{Nb}$ :Mo ratio in the $\mathrm{Nb}-\mathrm{Mo}-\mathrm{Si}-\mathrm{B}$ system [26].

It has been reported that after pack cementation coatings, the oxidation resistance increased for Mo-based alloys at high temperatures. For example, when Mo-Si-B alloys were coated via a Si pack cementation process, a MoSi 2 layer was produced at the surface, and the coated alloy showed excellent oxidation resistance up to about $1400^{\circ} \mathrm{C}$. At the same time, when $\mathrm{Nb}-\mathrm{Si}-\mathrm{B}$ alloys were Si pack coated, the $\mathrm{NbSi}_{2}$ layer was produced at the surface. It should be noted that the oxidation resistance of the coated $\mathrm{NbSi}_{2}$ layer was not excellent due to the formation of non-protective oxides, indicating that an optimum composition of the coated layer should be determined. Further, since the surface coating layer of $(\mathrm{Mo}$ or $\mathrm{Nb}) \mathrm{Si}_{2}$ is directly affected by the substrate composition, various substrate compositions should be investigated; this is the primary objective of this study.

In this study, in order to identify the optimal composition for the coating layer, various $\mathrm{Mo}-\mathrm{Nb}$ alloys which directly affect the surface coating layer were investigated. After Si pack cementation coatings were applied to $\mathrm{Nb}-\mathrm{Mo}$ alloys, oxidation resistance at $120{ }^{\circ} \mathrm{C}$ (that is, a higher temperature that that previously reported for the oxidation limits of $\mathrm{NbSi}_{2}$-coated alloys) was investigated from the viewpoint of microstructures. Based on the results, we offer guidelines for the appropriate $\mathrm{Nb}: \mathrm{Mo}$ ratio of substrates for potential Mo and $\mathrm{Nb}$-based alloys at $1200^{\circ} \mathrm{C}$. 


\section{Experimental Details}

The alloys were prepared by arc-melting using a tungsten electrode under an Ar atmosphere with six compositions in the $\mathrm{Nb}-\mathrm{Mo}$ system. Table 1 shows the compositions of the alloys. Prior to coating the samples, each sliced piece was polished with $\mathrm{SiC}$ paper and then ultrasonically cleaned. For the $\mathrm{Si}$ pack cementation coatings, three powders of $\mathrm{Si}, \mathrm{NaF}$, and $\mathrm{Al}_{2} \mathrm{O}_{3}$ were prepared. The weight ratio of the powder mixture was selected as $25 \mathrm{Si}-5 \mathrm{NaF}-70 \mathrm{Al}_{2} \mathrm{O}_{3}(\mathrm{wt} . \%)$. Then, the powder was mixed together and dried for $24 \mathrm{~h}$ at $70{ }^{\circ} \mathrm{C}$. The sliced alloy piece embedded in the mixed power were placed in alumina crucibles and sealed with alumina-based ceramic bonds. The sealed alumina crucibles were dried at room temperature for $24 \mathrm{~h}$, then placed in a furnace and annealed at $1100{ }^{\circ} \mathrm{C}$ for $24 \mathrm{~h}$ under an Ar atmosphere. A more detailed description of the specimen preparation procedure is given elsewhere [16]. The temperature of the furnace was raised at a rate of $5^{\circ} \mathrm{C} / \mathrm{min}$ and then held for the desired time. After heat treatment, the alumina crucibles were cooled to room temperature in the furnace.

Isothermal static oxidation tests to examine the oxidation behavior of the coating layer were carried out for $6 \mathrm{~h}$ at a temperature of $1200^{\circ} \mathrm{C}$ in air. When the desired oxidation time was reached, the specimen was pulled out the furnace and air cooled. After the oxidation tests, the samples were polished with $\mathrm{SiC}$ paper and then polished with $0.5 \mu \mathrm{m} \mathrm{Al}_{2} \mathrm{O}_{3}$ powder. In order to observe microstructural changes, scanning electron microscope (SEM, Hitachi SU5000, Ibaraki, Japan) was used, and energy-dispersive X-ray spectroscopy (EDS) (NanoAnalysis, High Wycombe, UK) was used for composition measurements. For phase analysis, X-ray diffraction (XRD, Rigaku, Akishima, Japan) was performed for the specimens without polishing (after coatings and after oxidation).

Table 1. Chemical composition of arc-melted $\mathrm{Nb}_{\mathrm{x}} \mathrm{Mo}_{\mathrm{y}}$ alloys (at.\%).

\begin{tabular}{ccc}
\hline Element. & Nb (at.\%) & Mo (at. \%) \\
\hline Alloy 1 & 100 & 0 \\
\hline Alloy 2 & 73.6 & 26.4 \\
\hline Alloy 3 & 51.2 & 48.8 \\
\hline Alloy 4 & 35.1 & 64.9 \\
\hline Alloy 5 & 25.7 & 74.3 \\
\hline Alloy 6 & 0 & 100 \\
\hline
\end{tabular}

\section{Results and Discussion}

Each $\mathrm{Nb}_{\mathrm{x}} \mathrm{Mo}_{\mathrm{y}}$ alloy prepared by arc-melting was identified by EDS analysis to determine the atomic percentage of the compositions (in Table 1). Figure 1 shows the results of the XRD patterns of the fabricated $\mathrm{Nb}_{\mathrm{x}} \mathrm{Mo}_{\mathrm{y}}$ alloys. Figure 1 shows the XRD results of Alloy $1(\mathrm{Nb})$, Alloy $2\left(\mathrm{Nb}_{73.6} \mathrm{Mo}_{26.4}\right)$, Alloy $3\left(\mathrm{Nb}_{51.2} \mathrm{Mo}_{48.8}\right)$, Alloy $4\left(\mathrm{Nb}_{35.1} \mathrm{Mo}_{64.9}\right)$, Alloy $5\left(\mathrm{Nb}_{25.7} \mathrm{Mo}_{74.3}\right)$, and Alloy $6(\mathrm{Mo})$, respectively. As the Mo content increases, the XRD peak shifts to the right. It appears that the peak shift is a well-known effect which occurs due to lattice parameter difference. While an analysis of the peak shift is needed, a detailed analysis will be shown elsewhere. 


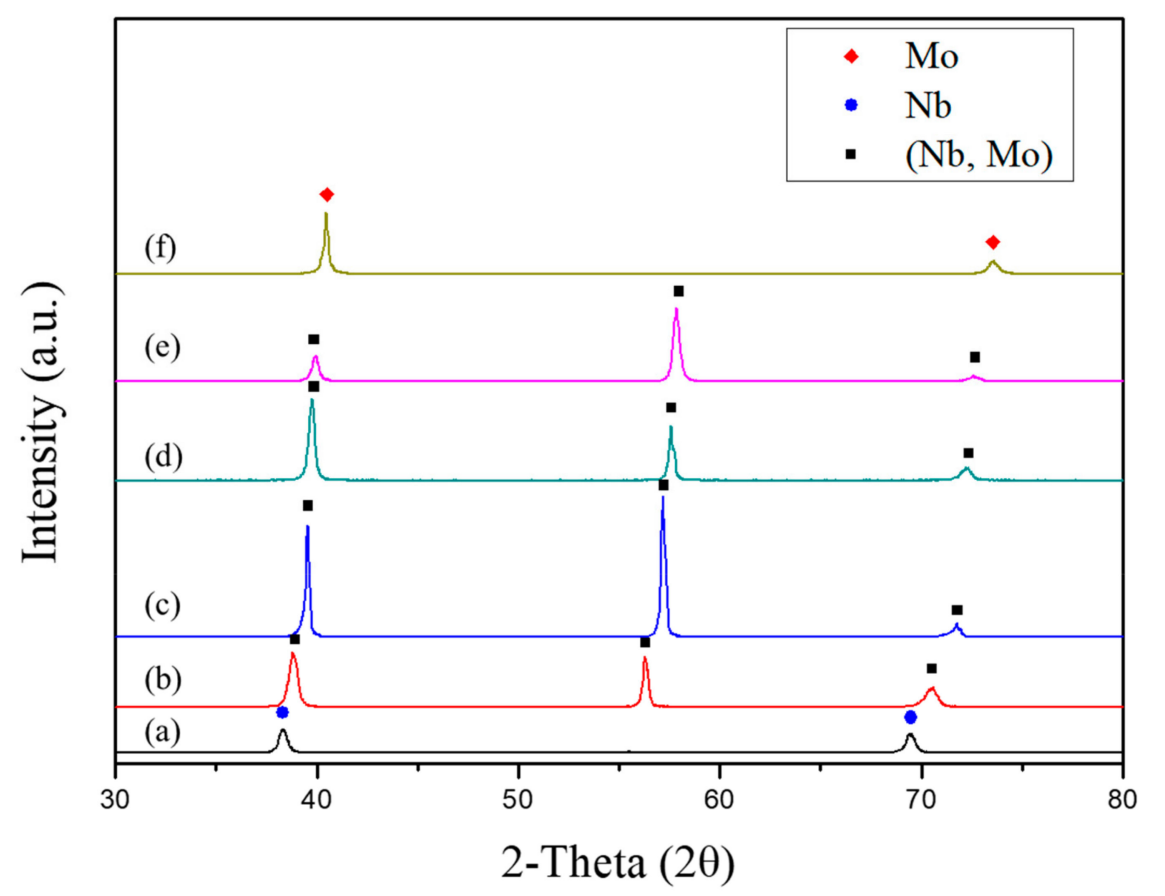

Figure 1. $\mathrm{XRD}$ patterns of the as-cast $\mathrm{Nb}-\mathrm{Mo}$ alloys with the compositions of (a) Alloy $1(\mathrm{Nb})$, (b) Alloy 2 $\left(\mathrm{Nb}_{73.6} \mathrm{Mo}_{26.4}\right)$, (c) Alloy $3\left(\mathrm{Nb}_{51.2} \mathrm{Mo}_{48.8}\right)$, (d) Alloy $4\left(\mathrm{Nb}_{35.1} \mathrm{Mo}_{64.9}\right)$, (e) Alloy $5\left(\mathrm{Nb}_{25.7} \mathrm{Mo}_{74.3}\right)$, and (f) Alloy $6(\mathrm{Mo})$.

Figure 2 shows SEM BSE images of a cross section of the Si-coated $\mathrm{Nb}_{\mathrm{x}} \mathrm{Mo}_{\mathrm{y}}$ alloys heated at $1100{ }^{\circ} \mathrm{C}$ for $24 \mathrm{~h}$. When the substrate was pure $\mathrm{Nb}$ (Figure 2a), the coated layer was identified as $\mathrm{NbSi}_{2}$ with a thickness of $\sim 27 \mu \mathrm{m}$; another coated layer was identified as $\mathrm{MoSi}_{2}$ with a thickness of $\sim 39 \mu \mathrm{m}$ at the surface (Figure 2f). However, when the composition of the substrate was changed, the coating layer composition was different. For the $\mathrm{Nb}-\mathrm{Mo}$ alloys (Alloys 2, 3, 4, and 5), a mixture of $\mathrm{Nb}$ and $\mathrm{Mo}$ silicide was identified, i.e., $\left(\mathrm{Nb}_{\mathrm{x}}, \mathrm{Mo}_{\mathrm{y}}\right) \mathrm{Si}_{2}$. Furthermore, another $\left(\mathrm{Nb}_{\mathrm{x}}, \mathrm{Mo}_{\mathrm{y}}\right)_{5} \mathrm{Si}_{3}$ layer formed between the substrate and the outer $\left(\mathrm{Nb}_{\mathrm{x}}, \mathrm{Mo}_{\mathrm{y}}\right) \mathrm{Si}_{2}$. Notably, in Alloy $3\left(\mathrm{Nb}_{51.2} \mathrm{Mo}_{48.8}\right)$, Alloy $4\left(\mathrm{Nb}_{35.1} \mathrm{Mo}_{64.9}\right)$, and Alloy $5\left(\mathrm{Nb}_{25.7} \mathrm{Mo}_{74.3}\right)$, the $\left(\mathrm{Nb}_{\mathrm{x}}, \mathrm{Mo}_{\mathrm{y}}\right)_{5} \mathrm{Si}_{3}$ phases were distributed in the $\left(\mathrm{Nb}_{\mathrm{x}}, \mathrm{Mo}_{\mathrm{y}}\right) \mathrm{Si}_{2}$ layer. The $\left(\mathrm{Nb}_{\mathrm{x}}, \mathrm{Mo}_{\mathrm{y}}\right)_{5} \mathrm{Si}_{3}$ phases of Alloy $5\left(\mathrm{Nb}_{25.7} \mathrm{Mo}_{74.3}\right)$ were generally distributed, but the $\left(\mathrm{Nb}_{\mathrm{x}}, \mathrm{Mo}_{\mathrm{y}}\right)_{5} \mathrm{Si}_{3}$ phases of Alloy $3\left(\mathrm{Nb}_{51.2} \mathrm{Mo}_{48.8}\right)$ and Alloy $4\left(\mathrm{Nb}_{35.1} \mathrm{Mo}_{64.9}\right)$ were distributed close to the substrate.

In fact, since the outer coating layer is significant for surface protection during oxidant exposure, the outer $\left(\mathrm{Nb}_{\mathrm{x}}, \mathrm{Mo}_{\mathrm{y}}\right) \mathrm{Si}_{2}$ layer was specially focused. Table 2 shows the results of the EDS measurements of the outer $\left(\mathrm{Nb}_{\mathrm{x}}, \mathrm{Mo}_{\mathrm{y}}\right) \mathrm{Si}_{2}$ coating layer. The $\mathrm{Nb}$ :Mo ratio in the $\left(\mathrm{Nb}_{\mathrm{x}}, \mathrm{Mo}_{\mathrm{y}}\right) \mathrm{Si}_{2}$ layer is shown for the Si-pack-coated alloys. The EDS measurements of the $\mathrm{NbSi}_{2}$ coating layer in Figure $2 \mathrm{a}$ and the $\mathrm{MoSi}_{2}$ coating layer in Figure $2 \mathrm{f}$ were confirmed to be about $\mathrm{Nb}: \mathrm{Si}=34.8: 65.2$ (at.\%) and about Mo: $\mathrm{Si}=35.3: 64.7$ (at.\%), respectively. Also, the EDS measurements of the $\left(\mathrm{Nb}_{\mathrm{x}}, \mathrm{Mo}_{\mathrm{y}}\right) \mathrm{Si}_{2}$ coating layers in Figure 2b-e were confirmed to be about Nb:Mo:Si = 26.9:8.5:64.6 (at.\%), 18.9:16.4:64.7 (at.\%), 12.5:23.1:64.4 (at.\%), and 9.0:27.4:63.6 (at.\%), respectively. Additionally, the Nb:Mo ratios in the silicide coating layers of each specimen were about 100.0/0, 76.0/24, 53.5/46.5, 34.8/64.2, 24.8/75.2, and 0/100.0 (at.\%), indicating that the outer coating layer may be expressed as $\left(\mathrm{Nb}_{\mathrm{x}}, \mathrm{Mo}_{\mathrm{y}}\right) \mathrm{Si}_{2}$. 
Table 2. EDS results of the $\left(\mathrm{Nb}_{\mathrm{x}}, \mathrm{Mo}_{\mathrm{y}}\right) \mathrm{Si}_{2}$ coating layer of Si-pack-coated $\mathrm{Nb}_{\mathrm{x}} \mathrm{Mo}_{\mathrm{y}}$ alloys (at.\%).

\begin{tabular}{cccc}
\hline Element & Nb (at.\%) & Mo (at.\%) & Si (at.\%) \\
\hline Alloy 1 & 34.8 & 0 & 65.2 \\
\hline Alloy 2 & 26.9 & 8.5 & 64.6 \\
\hline Alloy 3 & 18.9 & 16.4 & 64.7 \\
\hline Alloy 4 & 12.5 & 23.1 & 64.4 \\
\hline Alloy 5 & 9.0 & 27.4 & 63.6 \\
\hline Alloy 6 & 0 & 35.3 & 64.7 \\
\hline
\end{tabular}
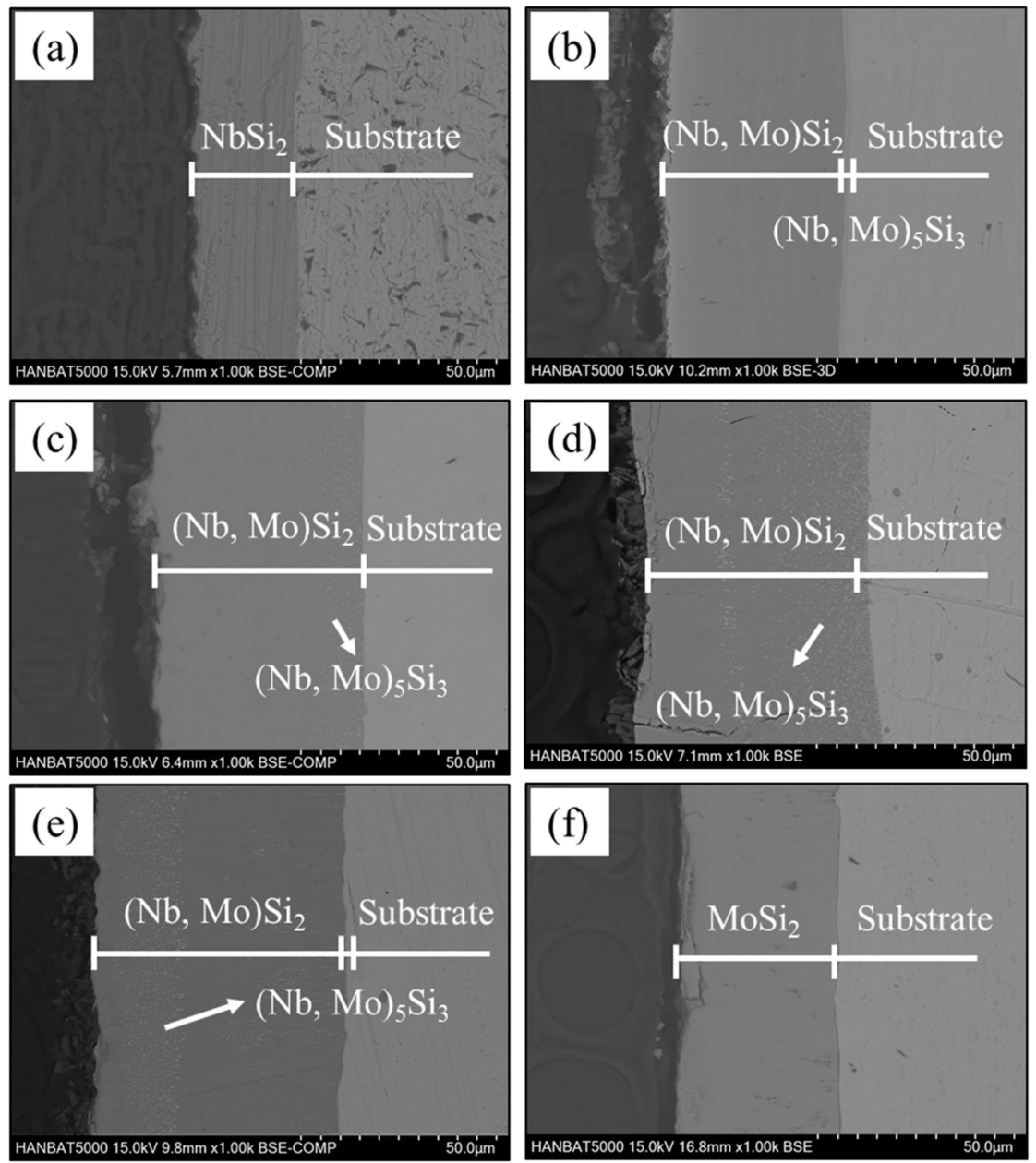

Figure 2. SEM BSE image of cross sections of Si-pack-coated specimens at $1100{ }^{\circ} \mathrm{C}$ for $24 \mathrm{~h}$ showing the formation of $\left(\mathrm{Nb}_{\mathrm{x}}, \mathrm{Mo}_{\mathrm{y}}\right) \mathrm{Si}_{2}$ and $\left(\mathrm{Nb}_{\mathrm{x}}, \mathrm{Mo}_{\mathrm{y}}\right)_{5} \mathrm{Si}_{3}$ coating layers on the surface with substrate compositions of (a) Alloy $1(\mathrm{Nb})$, (b) Alloy $2\left(\mathrm{Nb}_{73.6} \mathrm{Mo}_{26.4}\right)$, (c) Alloy $3\left(\mathrm{Nb}_{51.2} \mathrm{Mo}_{48.8}\right)$, (d) Alloy 4 $\left(\mathrm{Nb}_{35.1} \mathrm{Mo}_{64.9}\right)$, (e) Alloy $5\left(\mathrm{Nb}_{25.7} \mathrm{Mo}_{74.3}\right)$, and (f) Alloy $6(\mathrm{Mo})$.

Figure 3 shows the compositions of the substrates and the coated layer marked in the $\mathrm{Nb}-\mathrm{Mo}-\mathrm{Si}$ ternary phase diagram. Since the isothermal diagram was reported only both at $800{ }^{\circ} \mathrm{C}$ and $1300{ }^{\circ} \mathrm{C}$, a schematic isothermal phase diagram was presented to show the locations of the present alloy compositions and the coated layer compositions. The dotted arrows do not show a real diffusion pathway, but indicate that the coated layer compositions are closely related to the substrate compositions. As shown in Figure 3, the coated layer of $\left(\mathrm{Nb}_{\mathrm{x}}, \mathrm{Mo}_{\mathrm{y}}\right) \mathrm{Si}_{2}$ was changed with respect to the substrate compositions. It should be noted that the absence of the $\left(\mathrm{Nb}_{\mathrm{x}}, \mathrm{Mo}_{\mathrm{y}}\right)_{5} \mathrm{Si}_{3}$ phase in some alloys is possibly due to nucleation difficulties of resolution limitation, as indicated in previous papers [2,16]. Again, 
the dots in the phase diagram are from the EDS measurements from Tables 1 and 2. In turn, the present observations can be used in the design of coating layers with control of the substrate.

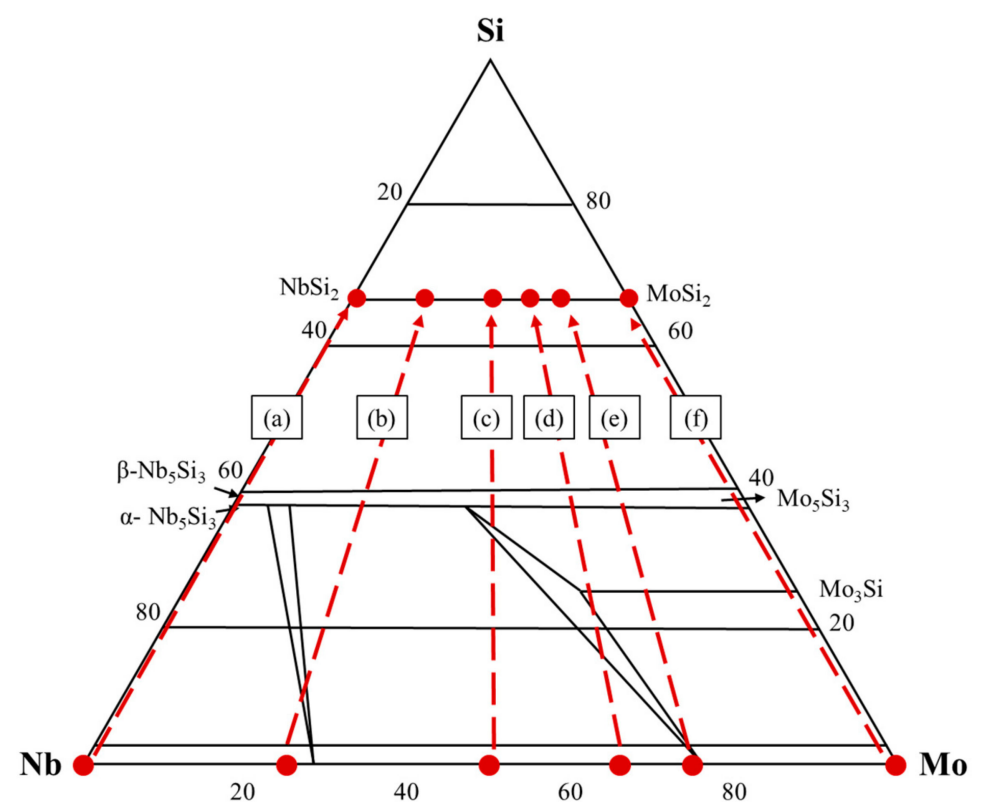

Figure 3. Schematic diagram of $\mathrm{Nb}-\mathrm{Mo}-\mathrm{Si}$ ternary phase diagram showing EDS measurements of substrates and coated layers. The points corresponding to the $\mathrm{Nb}-\mathrm{Mo}-\mathrm{Si}$ ratio of the Si-pack-coated $\mathrm{Nb}_{\mathrm{x}} \mathrm{Mo}_{\mathrm{y}}$ alloys are shown in the $\mathrm{Nb}-\mathrm{Mo}-\mathrm{Si}$ systems with the compositions of (a) Alloy $1(\mathrm{Nb})$, (b) Alloy 2 $\left(\mathrm{Nb}_{73.6} \mathrm{Mo}_{26.4}\right)$, (c) Alloy $3\left(\mathrm{Nb}_{51.2} \mathrm{Mo}_{48.8}\right)$, (d) Alloy $4\left(\mathrm{Nb}_{35.1} \mathrm{Mo}_{64.9}\right)$, (e) Alloy $5\left(\mathrm{Nb}_{25.7} \mathrm{Mo}_{74.3}\right)$, and (f) Alloy $6(\mathrm{Mo})$.

Figure 4 shows the XRD patterns of Si-pack-coated specimens at $1100{ }^{\circ} \mathrm{C}$ for $24 \mathrm{~h}$. When the alloy composition of $\mathrm{Nb}$ increased from 100 to 0 weight percent, the peak was changed. For example, with Alloy $1(\mathrm{Nb})$, only $\mathrm{NbSi}_{2}$ peaks were observed. With Alloy $6(\mathrm{Mo})$, only $\mathrm{MoSi}_{2}$ peaks were identified. However, when the substrate composition was between $\mathrm{Nb}$ and Mo, peaks of the $\left(\mathrm{Nb}_{\mathrm{x}}, \mathrm{Mo}_{\mathrm{y}}\right) \mathrm{Si}_{2}$ and $\left(\mathrm{Nb}_{\mathrm{x}}, \mathrm{Mo}_{\mathrm{y}}\right)_{5} \mathrm{Si}_{3}$ phase layers were detected. Further analysis will be given elsewhere.

As mentioned, $\mathrm{Nb}$-based alloys and/or $\mathrm{NbSi}_{2}$-coatedNb-based alloys do not maintain their original shape during oxidation exposure at $1200{ }^{\circ} \mathrm{C}$ [21], in contrast to $\mathrm{MoSi}_{2}$-coated Mo-based alloys [16]. In order to examine the oxidation resistance, oxidation tests were carried out at $1200^{\circ} \mathrm{C}$. Figure 5 shows the appearance of the Si-pack-coated specimens before and after the oxidation tests at $120{ }^{\circ} \mathrm{C}$ for $6 \mathrm{~h}$. After the oxidation tests, the Si-pack-coated Alloy $1(\mathrm{Nb})$ and Alloy $2\left(\mathrm{Nb}_{73.6} \mathrm{Mo}_{26.4}\right)$ appeared to be white due to the formation of $\mathrm{SiO}_{2}+\mathrm{Nb}_{2} \mathrm{O}_{5}$ on the surface. Notably, the surface oxide was peeled off from the surface, showing serious defects. Also, it can be seen that Alloy $3\left(\mathrm{Nb}_{51.2} \mathrm{Mo}_{48.8}\right)$ shows cracks on the surface after oxidation tests, and is not smooth, indicating that Alloy $1(\mathrm{Nb})$, Alloy 2 $\left(\mathrm{Nb}_{73.6} \mathrm{Mo}_{26.4}\right)$, and Alloy $3\left(\mathrm{Nb}_{51.2} \mathrm{Mo}_{48.8}\right)$ do not show oxidation stability. However, it was noted that Alloy $4\left(\mathrm{Nb}_{35.1} \mathrm{Mo}_{64.9}\right)$, Alloy $5\left(\mathrm{Nb}_{25.7} \mathrm{Mo}_{74.3}\right)$, and Alloy $6(\mathrm{Mo})$ show no changes in appearance, because the surface is protected by the formation of a stable $\mathrm{SiO}_{2}$ protective layer. 


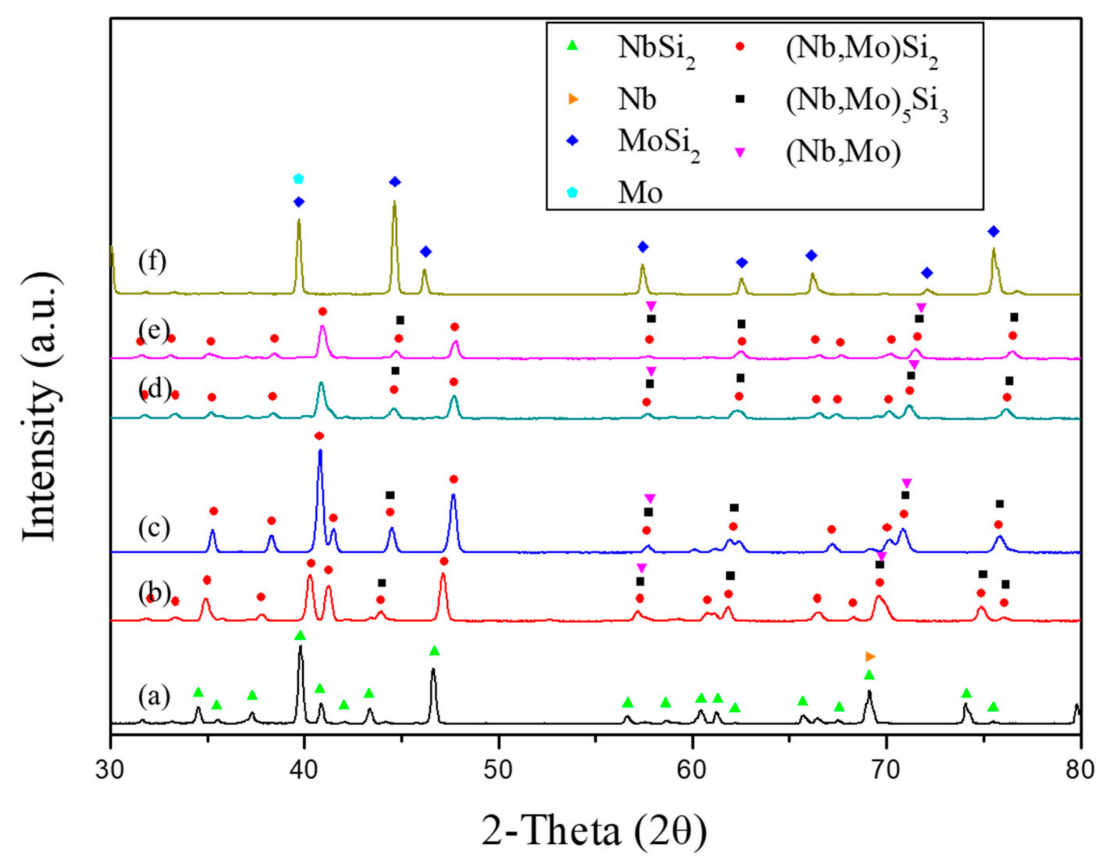

Figure 4. XRD patterns of Si-pack-coated specimens at $1100{ }^{\circ} \mathrm{C}$ for $24 \mathrm{~h}$ with the compositions of (a) Alloy $1(\mathrm{Nb})$, (b) Alloy $2\left(\mathrm{Nb}_{73.6} \mathrm{Mo}_{26.4}\right)$, (c) Alloy $3\left(\mathrm{Nb}_{51.2} \mathrm{Mo}_{48.8}\right)$, (d) Alloy $4\left(\mathrm{Nb}_{35.1} \mathrm{Mo}_{64.9}\right)$, (e) Alloy $5\left(\mathrm{Nb}_{25.7} \mathrm{Mo}_{74.3}\right)$, and (f) Alloy $6(\mathrm{Mo})$.

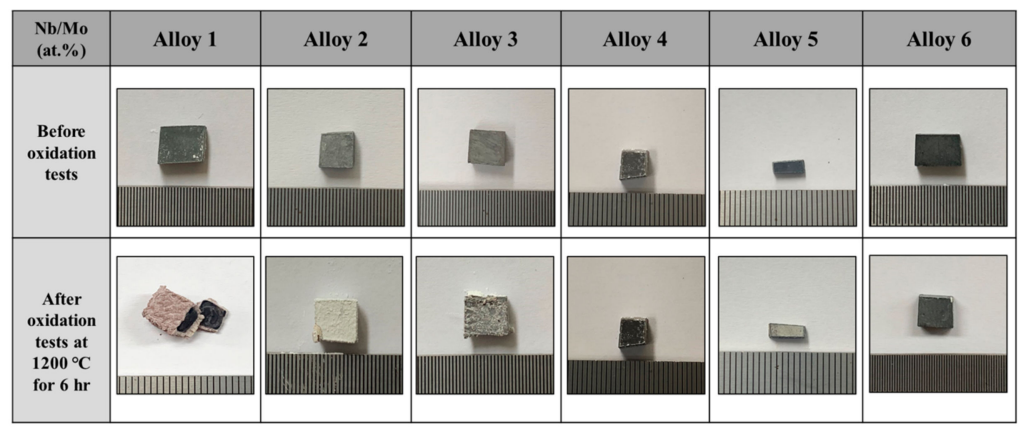

Figure 5. Images of Si-pack-coated specimens before and after oxidation tests at $1200^{\circ} \mathrm{C}$ for $6 \mathrm{~h}$.

Figure 6 shows SEM BSE images of the surface of the Si-pack-coated $\mathrm{Nb}_{\mathrm{x}} \mathrm{Mo}_{\mathrm{y}}$ alloys after the oxidation tests at $1200{ }^{\circ} \mathrm{C}$ for $6 \mathrm{~h}$. Regarding the pure $\mathrm{Nb}$ and pure Mo substrates, Figure $6 \mathrm{a}, \mathrm{f}$ show SEM BSE images of the surface of the coated Alloy $1(\mathrm{Nb})$ and Alloy $6(\mathrm{Mo})$ after the oxidation tests, respectively. The phase sequence was identified as $\mathrm{SiO}_{2}+\mathrm{Nb}$ oxide for the coated Alloy $1(\mathrm{Nb})$ and $\mathrm{SiO}_{2}+\mathrm{Mo}$ oxide for the coated Alloy 6 (Mo), respectively. Figure 6b-e show SEM BSE images of the surface of the coated Alloy $2\left(\mathrm{Nb}_{73.6} \mathrm{Mo}_{26.4}\right)$, Alloy $3\left(\mathrm{Nb}_{51.2} \mathrm{Mo}_{48.8}\right)$, Alloy $4\left(\mathrm{Nb}_{35.1} \mathrm{Mo}_{64.9}\right)$, and Alloy 5 $\left(\mathrm{Nb}_{25.7} \mathrm{Mo}_{74.3}\right)$ after the oxidation tests. Different from Figure $6 \mathrm{a}, \mathrm{f}$, mixed oxides of $\mathrm{SiO}_{2}$ and $\mathrm{Nb}_{2} \mathrm{O}_{5}$ with some Mo content were produced at the surface for the alloys of Alloy $2\left(\mathrm{Nb}_{73.6} \mathrm{Mo}_{26.4}\right)$, Alloy 3 $\left(\mathrm{Nb}_{51.2} \mathrm{Mo}_{48.8}\right)$, Alloy $4\left(\mathrm{Nb}_{35.1} \mathrm{Mo}_{64.9}\right)$, and Alloy $5\left(\mathrm{Nb}_{25.7} \mathrm{Mo}_{74.3}\right)$ as shown Figure $6 \mathrm{~b}-\mathrm{e}$. 

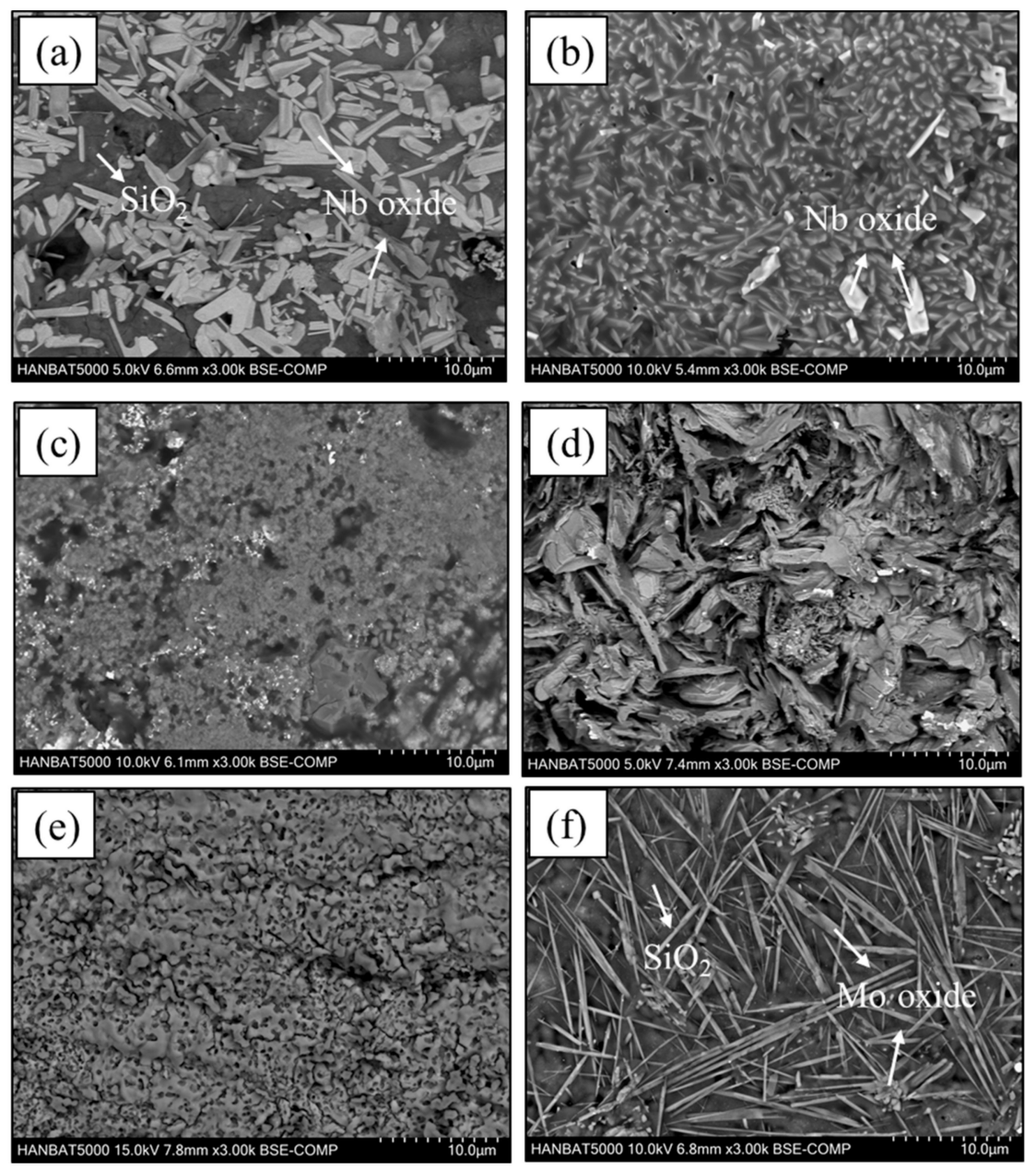

Figure 6. SEM image of the surface of Si-pack-coated specimens after oxidation tests at $1200{ }^{\circ} \mathrm{C}$ for $6 \mathrm{~h}$ with substrate compositions of (a) Alloy $1(\mathrm{Nb})$, (b) Alloy $2\left(\mathrm{Nb}_{73.6} \mathrm{Mo}_{26.4}\right)$, (c) Alloy $3\left(\mathrm{Nb}_{51.2} \mathrm{Mo}_{48.8}\right)$, (d) Alloy $4\left(\mathrm{Nb}_{35.1} \mathrm{Mo}_{64.9}\right)$, (e) Alloy $5\left(\mathrm{Nb}_{25.7} \mathrm{Mo}_{74.3}\right)$, and (f) Alloy 6 (Mo).

Figure 7 shows SEM BSE images of a cross section of the Si-pack-coated $\mathrm{Nb}_{\mathrm{x}} \mathrm{Mo}_{\mathrm{y}}$ alloys after the oxidation tests at $1200^{\circ} \mathrm{C}$ for $6 \mathrm{~h}$. Figure $7 \mathrm{a}$,f show SEM BSE images of cross sections of the coated Alloy $1(\mathrm{Nb})$ and Alloy $6(\mathrm{Mo})$ after oxidation tests, consisting of several layers. The phase sequence was identified as $\mathrm{SiO}_{2}+\mathrm{Nb}_{2} \mathrm{O}_{5} / \mathrm{NbSi}_{2} / \mathrm{Nb}_{5} \mathrm{Si}_{3} / \mathrm{Nb}$ for the coated Alloy $1(\mathrm{Nb})$ and $\mathrm{SiO}_{2} / \mathrm{MoSi}_{2} / \mathrm{Mo}_{5} \mathrm{Si}_{3} / \mathrm{Mo}$ for the coated Alloy $6(\mathrm{Mo})$. In the case of the coated Alloy $1(\mathrm{Nb})$, a Nb${ }_{5} \mathrm{Si}_{3}$ phase was also formed as a layer with a thickness of about $10 \mu \mathrm{m}$ between the $\mathrm{NbSi}_{2}$ layer and the substrate. Similarly, the $\mathrm{Mo}_{5} \mathrm{Si}_{3}$ layer in the coated Alloy 6(Mo) was also formed with a thickness of about $17 \mu \mathrm{m}$ between the $\mathrm{MoSi}_{2}$ layer and the substrate.

Figure $7 \mathrm{~b}$-e show SEM BSE images of cross sections of the coated Alloy $2\left(\mathrm{Nb}_{73.6} \mathrm{Mo}_{26.4}\right)$, Alloy 3 $\left(\mathrm{Nb}_{51.2} \mathrm{Mo}_{48.8}\right)$, Alloy $4\left(\mathrm{Nb}_{35.1} \mathrm{Mo}_{64.9}\right)$, and Alloy $5\left(\mathrm{Nb}_{25.7} \mathrm{Mo}_{74.3}\right)$ after the oxidation tests. Generally, the layer sequence was observed as an oxide layer/(Nb, Mo)Si $2 /(\mathrm{Nb}, \mathrm{Mo})_{5} \mathrm{Si}_{3} /$ substrate after the oxidation tests; the $\left(\mathrm{Nb}_{\mathrm{x}}, \mathrm{Mo}_{\mathrm{y}}\right)_{5} \mathrm{Si}_{3}$ layer was thicker than before the oxidation tests. In Figure $7 \mathrm{a}-\mathrm{c}$, some surface pores were found in the $\mathrm{SiO}_{2}$ oxide layer, indicating that the surface oxide was unprotected. However, Alloy $4\left(\mathrm{Nb}_{35.1} \mathrm{Mo}_{64.9}\right)$, which has a higher Mo content than Alloy $3\left(\mathrm{Nb}_{51.2} \mathrm{Mo}_{48.8}\right)$, was well protected by a $\mathrm{SiO}_{2}$ protective layer, indicating that the outer coating layer composition originating from substrates is a critical factor for the protection of the substrate. 

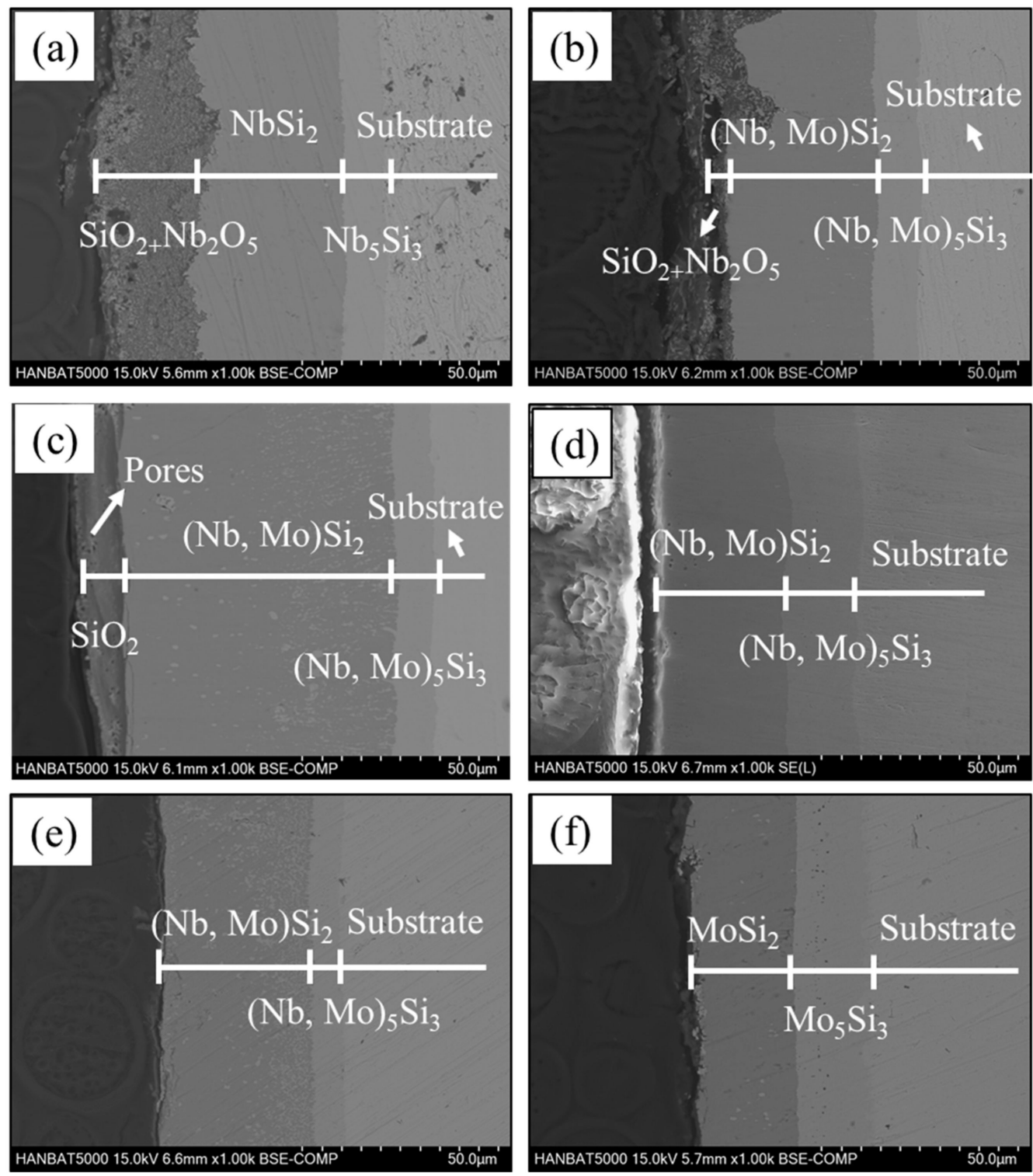

Figure 7. SEM BSE image of cross section of Si-pack-coated specimens after oxidation tests at $1200{ }^{\circ} \mathrm{C}$ for $6 \mathrm{~h}$ with substrate compositions of (a) Alloy $1(\mathrm{Nb})$, (b) Alloy $2\left(\mathrm{Nb}_{73.6} \mathrm{Mo}_{26.4}\right)$, (c) Alloy $3\left(\mathrm{Nb}_{51.2} \mathrm{Mo}_{48.8}\right)$, (d) Alloy $4\left(\mathrm{Nb}_{35.1} \mathrm{Mo}_{64.9}\right)$, (e) Alloy $5\left(\mathrm{Nb}_{25.7} \mathrm{Mo}_{74.3}\right)$, and (f) Alloy 6 (Mo).

In order to examine the surface oxides after the oxidation tests, XRD was carried out for all of the coated alloys. Figure 8 shows the XRD patterns of the Si-pack-coated specimens after oxidation tests at $1200{ }^{\circ} \mathrm{C}$ for $6 \mathrm{~h}$. As shown in Figure $8 \mathrm{a}, \mathrm{SiO}_{2}$ and $\mathrm{Nb}_{2} \mathrm{O}_{5}$ phases were observed when the content of $\mathrm{Nb}$ was increased in the $\mathrm{Nb}-\mathrm{Mo}$ alloys. 


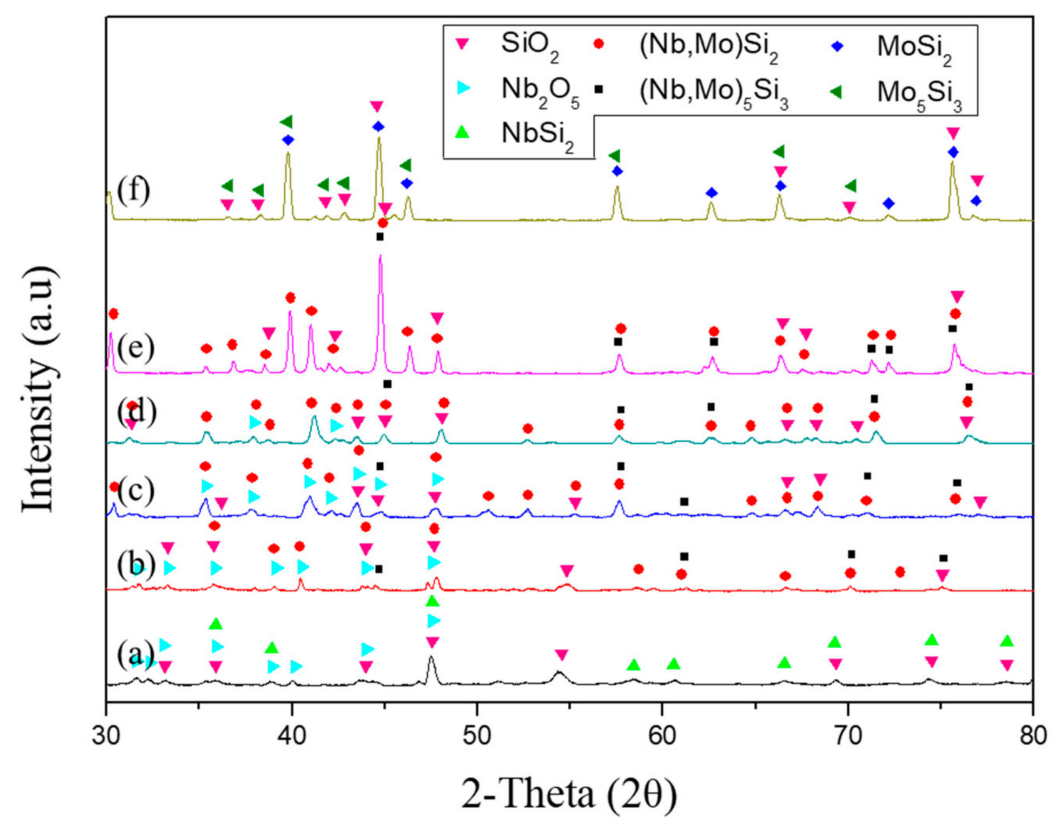

Figure 8. XRD patterns of Si-coated specimens after oxidation tests at $1200{ }^{\circ} \mathrm{C}$ for $6 \mathrm{~h}$ with substrate compositions of (a) Alloy $1(\mathrm{Nb})$, (b) Alloy $2\left(\mathrm{Nb}_{73.6} \mathrm{Mo}_{26.4}\right)$, (c) Alloy $3\left(\mathrm{Nb}_{51.2} \mathrm{Mo}_{48.8}\right)$, (d) Alloy 4 $\left(\mathrm{Nb}_{35.1} \mathrm{Mo}_{64.9}\right)$, (e) Alloy $5\left(\mathrm{Nb}_{25.7} \mathrm{Mo}_{74.3}\right)$, and (f) Alloy $6(\mathrm{Mo})$.

The weight changes after the oxidation tests with and without coatings are shown in Figure 9. When the specimens were not coated, about a $50 \%$ specific weight change was observed after oxidation. However, the coated specimens did not show any abrupt weight changes after oxidation for any of the alloys, as shown in Figure 9. It should be noted that for Alloy $1(\mathrm{Nb})$, Alloy $2\left(\mathrm{Nb}_{73.6} \mathrm{Mo}_{26.4}\right)$, and Alloy $3\left(\mathrm{Nb}_{51.2} \mathrm{Mo}_{48.8}\right)$, the oxides were composed of mainly $\mathrm{SiO}_{2}+\mathrm{Nb}_{2} \mathrm{O}_{5}$. When the substrate was alloys of Alloy $4\left(\mathrm{Nb}_{35.1} \mathrm{Mo}_{64.9}\right)$, Alloy $5\left(\mathrm{Nb}_{25.7} \mathrm{Mo}_{74.3}\right)$, and Alloy $6(\mathrm{Mo})$, the surface oxides were mainly $\mathrm{SiO}_{2}$ with some Mo oxides. As shown in Figure 5, after oxidation, the surface roughness increased for the coated pure $\mathrm{Nb}$ and $\mathrm{Nb}$-rich alloys, indicating that specific weight changes do not directly indicate the soundness of the alloys. Regarding this relationship, the oxidation of the coated surface $\left(\mathrm{Nb}_{\mathrm{x}}, \mathrm{Mo}_{\mathrm{y}}\right) \mathrm{Si}_{2}$ layers often undergoes a weight increase due to oxide formation at the surface, together with a weight reduction due to sublimation and/or pore formation, which affects weight changes after oxidation. Further investigation will be reported in order to identify structural evolution upon long-term exposure to high temperatures.

Figure 10 is a schematic illustration of the oxidation behavior of the coated $\mathrm{Nb}_{\mathrm{x}} \mathrm{Mo}_{\mathrm{y}}$ alloys at $1200{ }^{\circ} \mathrm{C}$. For Alloy $1(\mathrm{Nb})$, Alloy $2\left(\mathrm{Nb}_{73.6} \mathrm{Mo}_{26.4}\right)$, and Alloy $3\left(\mathrm{Nb}_{51.2} \mathrm{Mo}_{48.8}\right)$, a thick layer of $\mathrm{SiO}_{2}+\mathrm{Nb}_{2} \mathrm{O}_{5}$ formed on the surface, resulting from the oxidation of $\mathrm{NbSi}_{2} . \mathrm{Nb}_{2} \mathrm{O}_{5}$ is well known as a non-protective layer. The oxide produces pores when it forms at high temperatures, resulting in the severe damage that was observed for the $\mathrm{Nb}$-based alloys (Figure 10a). Figure 10b is a schematic diagram showing the oxidation behavior of coated Alloy $4\left(\mathrm{Nb}_{35.1} \mathrm{Mo}_{64.9}\right)$ and Alloy $5\left(\mathrm{Nb}_{25.7} \mathrm{Mo}_{74.3}\right)$ after oxidation tests. Since the $\mathrm{Nb}$ content is relatively low, the $\mathrm{Si}$ in the $(\mathrm{Nb}, \mathrm{Mo}) \mathrm{Si}_{2}$ layer reacted during oxidation to form a $\mathrm{SiO}_{2}$ oxide layer on the surface to suppress further oxidation. When the alloy is exposed to air at high temperatures, the produced $(\mathrm{Nb}, \mathrm{Mo}) \mathrm{Si}_{2}$ and $(\mathrm{Nb}, \mathrm{Mo})_{5} \mathrm{Si}_{3}$ coating layer protects the substrate. Figure 10c is a schematic diagram showing the oxidation behavior of the coated Mo alloy after oxidation tests. A thin layer of $\mathrm{SiO}_{2}$ oxide formed on the surface, where the $\mathrm{MoSi}_{2}$ and $\mathrm{Mo}_{5} \mathrm{Si}_{3}$ phases formed. In addition, as $\mathrm{Si}$ diffuses outward, the thickness of $\mathrm{Mo}_{5} \mathrm{Si}_{3}$ phase increases. 


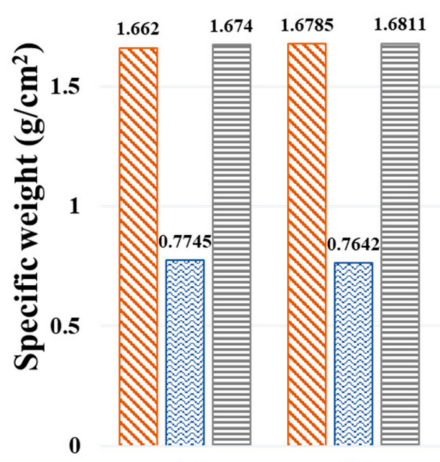

(a) (b)

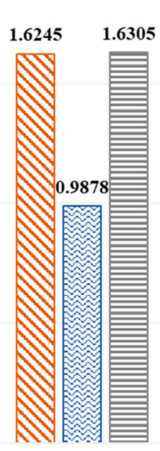

(c)

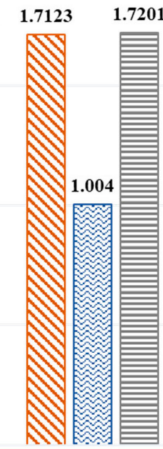

(d)

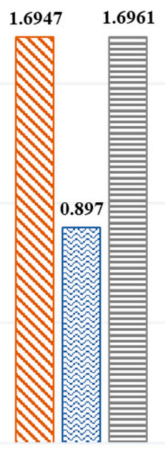

(e)

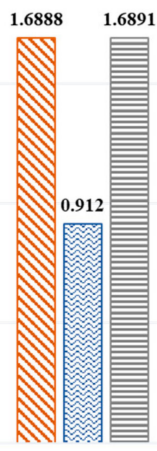

(f)

$\triangle$ Before oxidation tests 圆After oxidation tests (the uncoated specimens)

$\boxminus$ After oxidation tests (the $S i$ pack coated specimens)

Figure 9. Specific weight of uncoated and coated specimens with respected to alloy compositions of (a) Alloy $1(\mathrm{Nb})$, (b) Alloy $2\left(\mathrm{Nb}_{73.6} \mathrm{Mo}_{26.4}\right)$, (c) Alloy $3\left(\mathrm{Nb}_{51.2} \mathrm{Mo}_{48.8}\right)$, (d) Alloy $4\left(\mathrm{Nb}_{35.1} \mathrm{Mo}_{64.9}\right)$, (e) Alloy $5\left(\mathrm{Nb}_{25.7} \mathrm{Mo}_{74.3}\right)$, and (f) Alloy $6(\mathrm{Mo})$.
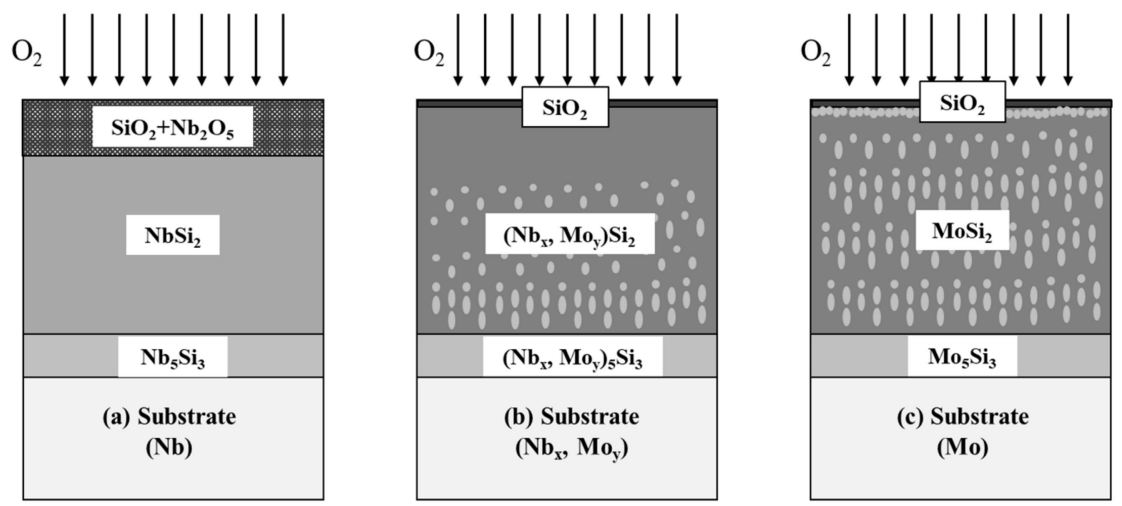

Figure 10. Schematic diagram of oxidation behavior of Si-pack-coated (a) Alloy $1(\mathrm{Nb})$, Alloy 2 $\left(\mathrm{Nb}_{73.6} \mathrm{Mo}_{26.4}\right)$ and Alloy $3\left(\mathrm{Nb}_{51.2} \mathrm{Mo}_{48.8}\right)$, (b) Alloy $4\left(\mathrm{Nb}_{35.1} \mathrm{Mo}_{64.9}\right)$ and Alloy $5\left(\mathrm{Nb}_{25.7} \mathrm{Mo}_{74.3}\right)$, and (c) Alloy 6 (Mo) after oxidation tests at $1200^{\circ} \mathrm{C}$.

It has been documented that $\mathrm{Nb}$ alloys usually do not have oxidation resistance at $1200^{\circ} \mathrm{C}$ due to the formation of porous oxide phases of $\mathrm{SiO}_{2}+\mathrm{Nb}_{2} \mathrm{O}_{5}$. Severe oxidation behavior occurs when the substrate is even coated with $\mathrm{NbSi}_{2}$. However, the present results show that when a certain amount of $\mathrm{Mo}$ is present in the $\mathrm{NbSi}_{2}$ layer, the surface $(\mathrm{Nb}, \mathrm{Mo}) \mathrm{Si}_{2}$ layer protects the substrate. While further investigation and phase analyses are needed, the present study clearly shows that an appropriate amount of $\mathrm{Mo}$ and $\mathrm{Nb}$ in the $\mathrm{Nb}_{\mathrm{x}} \mathrm{Mo}_{\mathrm{y}}$ substrates can protected the Si-pack-coated substrate at high-temperature exposure under an ambient atmosphere.

\section{Conclusions}

Refractory alloys, including $\mathrm{Nb}$ and $\mathrm{Mo}$, are among the candidates for use in high temperature materials. While Mo-based alloys have better oxidation resistance at higher temperatures than $\mathrm{Nb}$-based alloys, a high density of Mo often limits their application, resulting in the need for an optimum composition of $\mathrm{Nb}$ with $\mathrm{Mo}$ for high temperature applications. This study investigated the effect of oxidation behavior for silicide-coated alloys with various $\mathrm{Nb} / \mathrm{Mo}$ compositions $\left(\mathrm{Nb}_{\mathrm{x}} \mathrm{Mo}_{\mathrm{y}}\right.$ alloys). It was noted that the coating layer composition was significantly related to the substrate composition. With Si pack cementation coatings at $1100^{\circ} \mathrm{C}$ for $24 \mathrm{~h}, \mathrm{NbSi}_{2},\left(\mathrm{Nb}_{\mathrm{x}}, \mathrm{Mo}_{\mathrm{y}}\right) \mathrm{Si}_{2}+\left(\mathrm{Nb}_{\mathrm{x}}\right.$, $\left.\mathrm{Mo}_{\mathrm{y}}\right)_{5} \mathrm{Si}_{3}$, and $\mathrm{MoSi}_{2}$ coating layers formed with respect to the substrate alloy compositions. In order 
to examine the oxidation resistance, isothermal oxidation tests were carried out at $1200{ }^{\circ} \mathrm{C}$ for $6 \mathrm{~h}$. When the composition of $\mathrm{Nb}$ was up to 50 at.\%, the silicide layer did not protect the substrate due to the formation of porous $\mathrm{SiO}_{2}$ with $\mathrm{Nb}_{2} \mathrm{O}_{5}$ oxides. However, when the composition of $\mathrm{Nb}$ in the substrate was lower than $35 \mathrm{at} \%$, the silicide-coated substrates were successfully protected at $120{ }^{\circ} \mathrm{C}$. The present observations show that the $\mathrm{Nb}_{\mathrm{x}} \mathrm{Mo}_{\mathrm{y}}$ substrate compositions for retaining the oxidation resistance require a Mo content of at least $\mathrm{Nb}_{35} \mathrm{Mo}_{65}$ or higher for silicide pack coatings.

Author Contributions: W.Y. and J.S.P. conceived and designed the experiments; W.Y. performed the experiments; and C.-H.C., S.L. and J.W.L. made discussions; W.Y. wrote the paper.

Funding: This research was supported by research fund of Hanbat National University in 2017.

Conflicts of Interest: The authors declare no conflict of interest.

\section{References}

1. Dimiduk, D.M.; Perepezko, J.H. Mo-Si-B alloys: Developing a revolutionary turbine-engine material. MRS Bull. 2003, 28, 639-645. [CrossRef]

2. Perepezko, J.H. The hotter the engine, the better. Science 2009, 326, 1068-1069. [CrossRef] [PubMed]

3. Senkov, O.N.; Wilks, G.B.; Scott, J.M.; Miracle, D.B. Mechanical properties of $\mathrm{Nb}_{25} \mathrm{Mo}_{25} \mathrm{Ta}_{25} \mathrm{~W}_{25}$ and $\mathrm{V}_{20} \mathrm{Nb}_{20} \mathrm{Mo}_{20} \mathrm{Ta}_{20} \mathrm{~W}_{20}$ refractory high entropy alloys. Intermetallics 2011, 19, 698-706. [CrossRef]

4. Majumdar, S.; Gorr, B.; Christ, H.J.; Schliephake, D.; Heilmaier, M. Oxidation mechanisms of lanthanum-alloyed Mo-Si-B. Corros. Sci. 2014, 88, 360-371. [CrossRef]

5. Sossaman, T.; Sakidja, R.; Perepezko, J.H. Influence of minor Fe addition on the oxidation performance of Mo-Si-B alloys. Scr. Mater. 2012, 67, 891-894. [CrossRef]

6. Kim, Y.S.; Park, H.J.; Mun, S.C.; Jumaev, E.; Hong, S.H.; Song, G.; Kim, J.T.; Park, Y.K.; Kim, K.S.; Jeong, S.I.; et al. Investigation of structure and mechanical properties of TiZrHfNiCuCo high entropy alloy thin films synthesized by magnetron sputtering. J. Alloys Compd. 2019, 797, 834-841. [CrossRef]

7. Park, H.J.; Na, Y.S.; Hong, S.H.; Kim, J.T.; Kim, Y.S.; Lim, K.R.; Park, J.M.; Kim, K.B. Phase evolution, microstructure and mechanical properties of equi-atomic substituted TiZrHfNiCu and TiZrHfNiCuM $(\mathrm{M}=\mathrm{Co}, \mathrm{Nb})$ high-entropy alloys. Met. Mater. Int. 2016, 22, 551-556. [CrossRef]

8. Jumaev, E.; Hong, S.H.; Kim, J.T.; Park, H.J.; Kim, Y.S.; Mun, S.C.; Park, J.Y.; Song, G.; Lee, J.K.; Min, B.H.; et al. Chemical evolution-induced strengthening on $\mathrm{AlCoCrNi}$ dual-phase high-entropy alloy with high specific strength. J. Alloys Compd. 2019, 777, 828-834. [CrossRef]

9. Schneibel, J.H.; Kramer, M.J.; Easton, D.S. A Mo-Si-B intermetallic alloy with a continuous $\alpha$-Mo matrix. Scr. Mater. 2002, 46, 217-221. [CrossRef]

10. Parthasarathy, T.A.; Mendiratta, M.G.; Dimiduk, D.M. Oxidation mechanisms in Mo-reinforced $\mathrm{Mo}_{5} \mathrm{SiB}_{2}$ (T2)-Mo $\mathrm{Mo}_{3} \mathrm{Si}$ alloys. Acta Mater. 2002, 50, 1857-1868. [CrossRef]

11. Schneibel, J.H.; Ritchie, R.O.; Kruzic, J.J; Tortorelli, P.F. Optimization of Mo-Si-B intermetallic alloys. Metall. Mater. Trans. A 2005, 36, 525-531. [CrossRef]

12. Behrani, V.; Thom, A.J.; Kramer, M.J.; Akinc, M. Microstructure and oxidation behavior of Nb-Mo-Si-B alloys. Intermetallics 2006, 14, 24-32. [CrossRef]

13. Byun, J.M.; Bang, S.R.; Kim, S.H.; Choi, W.J.; Kim, Y.D. Mechanical properties of Mo-Nb-Si-B quaternary alloy fabricated by powder metallurgical method. Int. J. Refract. Met. Hard Mater. 2017, 65, 14-18. [CrossRef]

14. Chattopadhyay, K.; Balachandran, G.; Mitra, R.; Ray, K.K. Effect of Mo on microstructure and mechanical

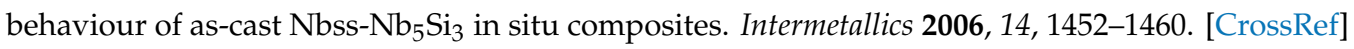

15. Takata, N.; Sekido, N.; Takeyama, M.; Perepezko, J.H.; Follett-Figueroa, M.; Zhang, C. Solidification of $\mathrm{Bcc} / \mathrm{T} 1 / \mathrm{T} 2$ three-phase microstructure in Mo-Nb-Si-B alloys. Intermetallics 2016, 72, 1-8. [CrossRef]

16. Choi, K.; Yang, W.; Baik, K.H.; Kim, Y.; Lee, S.; Lee, S.; Park, J.S. Growth kinetics and isothermal oxidation behavior of a Si pack cementation-coated Mo-Si-B alloy. Appl. Surf. Sci. 2019, 489, 668-676. [CrossRef]

17. Choi, K.; Kim, Y.J.; Kim, M.K.; Kim, M.K.; Lee, S.; Lee, S.; Park, J.S. Oxidation behavior of MoSi ${ }_{2}$-coated TZM alloys during isothermal exposure at high temperatures. Coatings 2018, 8, 218. [CrossRef]

18. Park, J.S.; Kim, J.M.; Kim, H.Y.; Yi, S.; Perepezko, J.H. Oxidation resistance coatings of Mo-Si-B alloys via a pack cementation process. Met. Mater. Int. 2008, 14, 1-7. [CrossRef] 
19. Majumdar, S. Isothermal and cyclic oxidation resistance of pack siliconized Mo-Si-B alloy. Appl. Surf. Sci. 2017, 414, 18-24. [CrossRef]

20. Cheng, J.; Yi, S.; Park, J.S. Oxidation behaviors of Nb-Si-B ternary alloys at $1100{ }^{\circ} \mathrm{C}$ under ambient. Intermetallics 2012, 23, 12-19. [CrossRef]

21. Cheng, J.; Yi, S.; Park, J.S. Oxidation behavior of $\mathrm{Nb}-\mathrm{Si}-\mathrm{B}$ alloys with the $\mathrm{NbSi}_{2}$ coating layer formed by a pack cementation technique. Int. J. Refract. Met. Hard Mater. 2013, 41, 103-109. [CrossRef]

22. Majumdar, S.; Kishor, J.; Paul, B.; Hubli, R.C.; Chakravartty, J.K. Isothermal oxidation behavior and growth kinetics of silicide coatings formed on $\mathrm{Nb}-1 \mathrm{Zr}-0.1 \mathrm{C}$ alloy. Corros. Sci. 2015, 95, 100-109. [CrossRef]

23. Lange, A.; Braun, R. Magnetron-sputtered oxidation protection coatings for Mo-Si-B alloys. Corros. Sci. 2014, 84, 74-84. [CrossRef]

24. Nomura, N.; Suzuki, T.; Yoshimi, K.; Hanada, S. Microstructure and oxidation resistance of a plasma sprayed Mo-Si-B multiphase alloy coating. Intermetallics 2003, 11, 735-742. [CrossRef]

25. Sakidja, R.; Rioult, F.; Werner, J.; Perepezko, J.H. Aluminum pack cementation of Mo-Si-B alloys. Scr. Mater. 2006, 55, 903-906. [CrossRef]

26. Liu, Y.; Kramer, M.J.; Thom, A.J.; Akinc, M. Oxidation behavior of multiphase Nb-Mo-Si-B intermetallics. Metall. Mater. Trans. A 2005, 36, 601-607. [CrossRef]

(C) 2019 by the authors. Licensee MDPI, Basel, Switzerland. This article is an open access article distributed under the terms and conditions of the Creative Commons Attribution (CC BY) license (http://creativecommons.org/licenses/by/4.0/). 